\title{
Empirical Analysis of Balance of Payment Adjustment Mechanisms: Monetary Channel in Nigeria, 1970- 2010
}

\author{
Julius 0 . Tijani \\ Email:juliustijani@yahoo.com
}

\section{Doi:10.5901/mjss.2014.v5n14p67}

\section{Abstract}

This study attempt is toward understanding the application of monetary approach as adjustment mechanism to correct balance of payments dis-equilibrium. It examined the review of empirical studies of the theory in Nigeria, explained the observed behavior of Nigeria's balance of payments. It also aimed at the verification or refutation of monetary theory in Nigeria's balance of payments adjustment mechanisms, given that any theory irrespective of its elegance in clarification or its sound logical reliability cannot be established and generally accepted without some empirical testing. The study was piloted via linear regression analysis using data from 1970 to 2010. The estimated result shows a positive relationship between the dependent variable (Balance of Payments) and the Independent variables (Domestic Credit, Exchange Rate andBalance of Trade)while (Inflation Rate and Gross Domestic product) are otherwise. It concludes that though not entirely, monetary measures constitute immensely to the position of BOP, cause disturbances and also serve as adjustment mechanism to bring BOP to equilibrium depending on it application and policy mix by monetary authority. However, it recommends that the government through Central Bank of Nigeria (CBN) should apply expenditure reducing monetary policies through money supply and domestic credit to promote favourable BOT which invariably stabilizes BOP.

Keywords: Balance of Payment, Adjustment mechanism, Monetary Theory, Channel, Policies, Exchange Rate, Domestic Credit, Inflation Rate, Gross Domestic Product

\section{Introduction}

There have been emergence of different school of thoughts from time to time on the balance of payment adjustment, the Classical approach (1800 - 1900), centered on gold standard and emphasized on role of prices and interest rate, it major shortcomings are that flows of gold are indirectly related to domestic money supply, any fall in money supply reduces output and employment rather than prices, full employment is unattainable which invariably make prices increases as money supply increases. Also inflows of gold increase the money supply leading to a fall in short term interest rate. These shortcomings led to the relevance of the Keynesian approach from 1930 to till present. This stressed on income changes affecting adjustment, some of it shortcomings are that countries with surplus in income experience rising national income, leading to an increased demand for imports- partially offsetting the surplus, this is otherwise for the deficit nations. If two countries trade as one country experiences deficit, another country experiences surplus, so that while income is increasing in one country, its export decline to the country with rising income. In order to overcome the portend shortcomings of these approaches, Monetary approach (1960- Chicago School) was developed as the modern approach, this focus on role of money in changes and adjustment. And that BOP disequilibrium represents an imbalance between the supply and demand for money. Excess supply of money encourages imports, which results in foreign exchange reserves flowing overseas and reducing the money supply Carbaugh (2004).

This modern approach was propounded and originated by Polak (1957) and his colleagues which focal point is on the perspective that the balance of payments of any particular country is in actual fact a monetary trend, this was further built up by Mundell and Johnson $(1968,1972)$. Mundell established that 'monetary policy is more effective than fiscal policy, in attaining external balance, basically because monetary policy improved both the current and capital accounts of the balance of payments' Mundell (1968). However, many latest studies related to this concept have been linked to the internal and external balance of Meade Tinbergen of 1950s. Assumably therefore, it was this focus on monetary policy and on the overall balance-of-payments position, coupled with the gradual realization with perfect capital mobility that the money supply ceased to be controlled by the monetary authorities even in the short-run that led Mundell and Johnson to develop the modern monetary approach. Thus Mundell and Johnson with the assistance of graduate students at the University of Chicago were led to develop on entirely different analytical framework and offer it as a substitute for the 
traditional approaches. What emerged was a cohesive body of theory that becomes known as the monetary approach to the balance of payments (Kreinin and Officer, 1978).

The essence of the approach is a consistent insistence that the balance of payments is monetary and not a real phenomenon as asserted by the conventional theories. The major point of departure of the modern approach is the identification of the fact that a country imbalance of payments, deficit (surplus) would experience a change in its money stock, ceteris paribus. The consistent deficits run down the stock of money and perennial surpluses build up the stock and after some time, the spending pattern changes such that the imbalance is rapidly eliminated (Johnson 1972). The main distinctive attribute of the modern approach to payments problem is its focus upon the monetary implications of balance of payments disequilibria. Those balance of payments problems are monetary in nature in a monetary economy world this is basically the assertion of the proponents of the approach. Therefore the relevant concept of the balance of payments refers specifically to the official settlement balance or the money account (Musa, 1976).

Achieving internal and external stability in balance of payment disequilibrium is undoubtedly the primaries aim of monetary theory to balance of payment. However, two phases were devised, which are before and after the Structural Adjustment Programme in Nigeria (SAP) of 1986. The first phase placed importance on direct monetary control, the economic environment associated with monetary phenomenon before 1986 was characterized by the dominance of all sector in the economy and over dependence on the external sector. The major sources of problem in monetary management were the nature of the monetary framework, the interest rate regime and non-harmonization of fiscal and monetary policy, the oil boom era that led into rapid monetization of foreign exchange earnings resulted in large increase in government expenditure which contributed to monetary instability in the early 1980's. In order to maintain price stability and healthy balance of payment position, the monetary control framework relied heavily on the use of direct monetary instrument such as credit ceiling, selective credit control, interest rate, exchange rate, cash reserve requirement and special deposit. The use of market based instrument was not feasible at that point because of the under development nature of the financial market and deliberately restraint on interest rate. The most accepted instrument of monetary policy as a concept of monetary phenomenon was the issuance of credit rationing guidance.

The second phase relied on market mechanism, the objectives of monetary phenomenon since 1986 have remained the same as in the earlier period for the stimulation of output on employment promotions of internal and external stability. The main instrument of the market base framework is the open market operation, this is complemented by reserve requirement and discount window operation. Moreover, the introduction of Structural Adjustment Programme (SAP) was adopted in July 1986, the reintroduction of the Dutch Auction System (DAS) of foreign exchange management in July 2002 and introduced a set of prudential guideline for licensed banks in 1990 were policy measures adopted and designed to promote a stable macro-economic environment to achieve a non-inflationary output growth and for the deregulation of external trade and payment arrangements, achieving fiscal balance and monetary balance of the balance of payment viability and the adoption of a market force as a major determinant of economic activity (CBN Report 2006).

The study looked into the monetary channel of balance of payment adjustment mechanism in Nigeria with a special reference to 1970 - 2010. The data used for the estimation of the study were sourced from Central Bank of Nigeria (CBN), statistical bulletin, National bureau of Statistic (NBS) International Monetary Fund (IMF), World Bank Organization for Economics Co-operation and Development (OECD). However, most of the secondary information or data were got from these institutions through internet browsing, while others were got from their respective offices in Nigeria. Also different articles and journals were also examined. This research made use of regression analysis to establish a mathematical relationship between monetary variables/channel (domestic credit, balance of trade, national output, price level and exchange rates) alongside the balance of payment in Nigeria and reviewed of past empirical studies using Nigeria as empirical evidence, to test the theoretical proposition of monetary approach to balance of payment adjustment mechanism. The $\mathrm{H}_{0}$ and $\mathrm{H}_{1}$ are specified thus; $\mathrm{H}_{0}$ : Monetary channel has insignificant role in the balance of payment adjustment mechanism in Nigeria. $H_{1}$ : Monetary channel has significant role in the balance of payment adjustment mechanism in Nigeria.

\section{Empirical Review and Theoretical Framework}

It is important to examine some literatures findings on the monetary approach of balance of payment adjustment mechanisms. In a study of Monetary Approach of Balance of Payment in West African Monetary Zone by Adamu and Itsede (2010), using three estimation methods, GGM system, Fixed-effects OLS and Differenced GMM. Their findings indicated that a log of GDP had a positive effect on the change in net foreign assets. This implies that a country's income plays a significant role for its net assets. The result also showed that estimated coefficient on the change in domestic credit is found to be statistically significant at 1 percent and consistent with the monetary approach of balance of 
payment. A negative relationship between domestic credit and net foreign asset was established for all the three models. This implies that an increase in domestic credit worsens the balance of payment, this result consistent with theoretical explanations. The result also showed that inflation is not a strong determinant of the balance of payment position in the West African Monetary Zone. Their conclusion for both within-country and cross-country effects suggest that it is indeed applicable. The findings specifically indicated that monetary approach to balance of payment holds in the countries and the growth in domestic credit is an important determinant of their balance of payments position. Similar result was obtained by Imoisi (2012) in the case of Nigeria, where the relationship between BOP and inflation rate was insignificant while the relationship between BOP, exchange rate and interest rate was significant which is in conformity with the economy theory.

Alexander D. (2013) in a study of Ghana BOP Monetary approach form 1980-2010 using Dicker Fuller model. He found that inflation is statically insignificant but $1 \%$ increase in domestic credit leads to $6.6 \%$ decrease in reserve, which implies that excessive generation of credit causes discrepancy in reserve. He concludes that though monetary variables are not solely responsible for the disequilibrium in balance of payment, factor such as government expenditure also play a role. Obioma (1998) used data for 1960-1993 to test the validity of monetary approach to balance of payment adjustment for Nigeria under fixed and flexible exchange regimes. He found that an increase in domestic credit on money stock leads to external reserves outflow or adverse balance of payment during the fixed exchange rate regime. But in the flexible exchange rate era, an increase in domestic credit brings about exchange rate depreciation. Jimoh (2004) using data from 1960-1995, also found that the monetary approach is relevant in analyzing balance of payments adjustments in Nigeria. Dhliwayo $(1996,2004)$ used data for the period 1980-1991 to investigate the monetary approach to balance of payment in Zimbabwe. His findings indicate a one to one negative relationship between domestic credit and the flow of international reserves. The empirical results validate the MABP in Zimbabwe. This implies that money plays a significant role in the determination of deficit in the balance of payments. In a related development, a study by Imoisi et al (2013) to examine the impact of monetary policy on balance of payment stability in Nigeria from 1980 to 2010 . They found that money supply, exchange rate and balance of payment have positive relationship while interest rate is negatively related to balance of payment.

This is similar to a study by Nwani (2003), he investigates the long-run determinants of balance of payment dynamics in Nigeria between 1981 and 2002, using econometric method of cointegration and error correction mechanism. He found that all the variables except balance of payment, exhibited non-stationarity. The results also indicate that balance of payment cointegrated with all the identified explanatory variables, suggesting that balance of payment fluctuations in Nigeria could be caused by the level of trade openness, external debt burden, exchange rate movement and domestic inflation. We concluded that a reduction in fiscal deficits, an increased domestic production through private investment, inflation targeting and regulated capital market integration are the panacea to the negative fluctuation in the Nigerian balance of payment.

It was revealed from a study by Akpansung (2013), when the balance of payment of Nigeria and some other countries were indiscriminately chosen and reviewed by him. The study stated that most of the empirical studies of monetary approach reviewed established stability of money demand functions and also showed evidence of causal relationships that exist between domestic credit and balance of payments. The growth in income and prices have positive effect on balance of payments (i.e surpluses), while growth in the domestic credit have negative effect on balance of payments (i.e deficits) which results intoreserve outflows. This also mean that 'balance of payments is evidently a monetary phenomenon' Mundel (1968). As a result, to cleverly correct any disequilibrium in a country's reserves, adjustment of domestic credits demand and foreign trade balance's size, Akpansung (2013). According to Akpansung, a side-by-side employment of both devaluation and restrictive monetary policies by the monetary authorities was predicted especially in the absorbing and third world countries, like Nigeria, Akpansung $(1998,2013)$. Nevertheless, this conclusion is slightly in variance to the modified monetary approach to devaluation as propounded by Johnson and Frenkel (1978) and elaborated by Connolly and Taylor $(1976,1979)$ which was employed by Nyong and Obafemi (1995).

According to Nyong and Obafemi (1995), they adopted a modified monetary approach to devaluation as propounded by Johnson and Frenkel $(1978)$ and elucidated by Connolly and Taylor $(1976,1979)$ in a study to investigate the Impact of Exchange Rate Adjustments (Devaluation) in Nigeria's Balance of Payments from 1960-1993. Their simultaneous equations model was modified in a specific form as thus:

1. $\partial \mathrm{BOP} / \mathrm{M}=\emptyset_{0}+\emptyset_{1} \partial \mathrm{R} / \mathrm{R}+\emptyset_{2} \partial \mathrm{DOM} / \mathrm{M}+\emptyset_{3} \mathrm{SAP}+\emptyset_{4} \partial \mathrm{BOP} / \mathrm{M}(-1)+\mu_{1}$

2. $\partial \mathrm{BOP} / \mathrm{M}=\emptyset_{0}+\emptyset_{1} \partial \mathrm{BOP} / \mathrm{M}+\emptyset_{2} \partial 10 \mathrm{gGDP}+\emptyset_{3} \mathrm{SAP}+\emptyset_{4} \mathrm{LENDR}+\mu_{2}$

Where,

$\mathrm{BOP}=$ balance of payments position at time $\mathrm{t}$,

$\mathrm{M}=$ broad money supply (M2) at time $\mathrm{t}$. 
$\partial \mathrm{BOP} / \mathrm{M}(-1)=$ one period lag of the variable.

$\mathrm{R}=$ exchange rate at time $\mathrm{t}$.

SAP = dummy variable which takes value of 0 from 1962-1985, and 1 from 1986-1993.

$\log (G D P)=$ logarithm of GDP at time t.

LENDR = lending rate at time t;

$\mu 1, \mu 2=$ stochastic error terms with the-usual properties of normality and constant variance.

Their empirical results according to Akpansung (2013) was rested on two stage-least squares estimating procedures and effective estimation period from 1962-1993. This therefore revealed that: (i) the devaluation coefficient (ø1) was statistically not significant and had a wrong sign, the size of the coefficient was far from unity, conforming to the a priori expectation. This implies that devaluation may not correct the disequilibrium in Nigeria's balance of payments, all things held constant. (ii) The growth in domestic credit was an important source worsening the Nigeria's balance of payments position. (iii) The coefficient on change in domestic credit (ø2) was not only close to unity but different from unity as predicted by the monetary approach. That is, the domestic credit coefficient (ø2) was found to be -0.8746 instead of -1.00 as a priori expected. The coefficient was statistically significant at about 5 per cent level. (iv)The sterilization or neutralization coefficient (ù1) was statistically significant at better than one per cent level. This result implies that the Central Bank of Nigeria carried out complete neutralization of the domestic money supply within the sampled period (i.e 1960-1993). (v) Their model failed to track the actual effect of the 65 per cent devaluation in 1986 (where the Naira was devalued by 65 percent, trading vis-à-vis the US dollar at $\$ 1=\mathrm{N} 4.60$ as against the administered rate of $\$ 1=\mathrm{N} 1.60$, during September 26, 1986 SFEM auction).

Based on their empirical results and analysis, Nyong and Obafemi (1995) concluded that devaluation as a policy response to redress the disequilibrium in Nigeria's external sector was an inappropriate policy response to the fundamental disequilibrium plaguing the Nigerian economy. They went further to identify various factors responsible for the inapplicability of the monetary approach to devaluation in the Nigerian context to include the structure of Nigeria's production, imports and exports coupled with instability in the macro economy, political instability and unpropitious institutional environment. However, their study indicated the crucial role of domestic credit in macro-economic adjustment. Akpansung (2013). Taiwo (1992), using Bayesian Posterior Odds Ratio, ten (10) sampled African countries from 1960 - 1990, to assess their balance of payments crisis. He concluded that about 50 per cent of the countries sampled were experiencing a fundamental disequilibrium in their current and capital accounts. Among others, his results indicated that Nigeria was not yet experiencing this severe problem but that it would take her approximately four years to attain equilibrium in the current account, if nothing else disturbed the system. He noted however, that the economic crisis facing most African countries (including Nigeria) is multi-dimensional, and must not in any way be compared with the balance of payments predicament these countriesare facing. He also anticipated the imminent self-correcting propensity of the countries without severe balance of payments deficits. He recommended that countries having elementary disequilibrium in their balance of payments should employextreme measures derivable from any of the appropriate theory of balance of payments, such as the monetary, according to Akpansung (2013).

Effort by Akpansung to establish the applicability of the monetary approach to the balance of payments in Nigeria (1960 -1995), using a two stage least squares (2SLS) estimation technique with relevant monetary variables, Akpansung (1998) estimated simultaneous equations model of reserve-flow equation and the sterilization equation, thus:

3. $\partial R / H=\delta_{0}+\delta_{1} \partial P / P+\delta_{2} \partial Y / Y+\delta_{3} \partial r / P-\delta_{4} \partial M / M-\delta_{5} \partial D / H+u_{1} \ldots \ldots .$.

4. $\partial D / H=\ddot{e}_{0}+\ddot{e}_{1} \partial R / H+\ddot{e}_{2} \partial G D O S / G D O S+u_{2} \ldots \ldots$.

Where $\mathrm{H}$ is the high-powered money, defined as the sum of the international reserves $(\mathrm{R})$ and total cash in circulation $(C), m$ is the money multiplier, $P$ is the price level, $Y$ denotes income, $D$ equals domestic credit, $r$ is the interest rate, and GDOS stands for government debt outstanding. The sterilization or offsetting or government reaction function (equation 12) assumes that open market operations by the central bank are determined by the change in international reserves (the offsetting hypothesis) and the change in government external debt outstanding (since the central bank is a large source of finance for the government). However, the empirical result showed that Nigeria's balance of payments has been dominated by monetary variables. The result confirmed the postulate that reserve accumulation is negatively related to the rate of growth of domestic output.

Jimoh (2004) also used both the Nigerian monthly and annual data between 1987 and 2001 to determine the relevance of the monetary approach to floating exchange rate regime operable in Nigeria since 1987. Fitting some of the most commonly used models for testing the relevance of monetary approach to floating rates analysis on Nigerian data, Jimoh found that those monetary models provided an adequate representation of the Nigerian data. Jimoh (2004); ctited by Akpansung (2013). The message from above is that there appear to be a very significant relationship between balance of payments and domestic credit, exchange rate (devaluation) as well as income and prices but inappropriateness and 
misspecification of monetary policies generally lead to balance of payments deficits and reserve outflows.

\subsection{The Monetary Theory Of Balance Of Payment}

Alexander's (1952) presentation of the absorption approach contains seeds of the monetary approach to balance of payments, which sprang out in the 1960s as part of the monetarist anti-Keynesian revival. The theoretical analysis of the monetary approach comes from the writings of Mundell (1968), Johnson (1975, 1976, 1977), and Mussa (1976), even though the arguments for the relationship between the foreign sector and the domestic sector of an economy through the working of the monetary sector can be traced to Hume's (1752) price specie flow mechanism. The monetary approach observes balance of payments instability as disequilibrium in the demand and supply of money stock. This approach analysis is centers on the monetary-account of the balance of payments in the context of a general equilibrium analysis. Thus, "the balance of payments is a monetary and not a real phenomenon and balance of payments disequilibria are stock and not flow disequilibria" (Johnson 1975).

The formal monetary approach to balance of payments model based on Johnson (1976) specifies a money supply identity, a money demand function and an equilibrium condition.

The model consists of the following set of equations:

1. $M^{s}=(R+D)$

2. $M^{d}=L(Y, P, I)$

3. $M^{s}=M=M^{d}$...........

Where:

$\mathrm{M}^{\mathrm{s}}=$ money supply;

$\mathrm{R}=$ international reserves;

$\mathrm{D}=$ domestic credit;

$\mathrm{M}^{\mathrm{d}}=$ money demand;

$V=$ level of real domestic income;

$\mathrm{P}=$ price level;

$\mathrm{I}=$ rate of interest; and

$M=$ equilibrium stock of money.

Equation 6 postulates that money supply is determined by the availability of international reserves and the level of domestic credit created by the country's monetary reserves, while Equation 7 sets out the real demand for money as a function of real income, the inflation rate and the interest rate. The monetary theory states that there is a positive relationship between money held and income $\left(\partial M^{d} / \partial Y>0\right)$ and money held and the price level $\left(\partial M^{d} / \partial P>0\right)$, and a negative relationship between money held and the interest rate $\left(\partial \mathrm{M}^{\mathrm{d}} / \partial \mathrm{I}<0\right)$. Equation 8 is the equilibrium condition in the money market. By combining Equations 6,7 and 8, placing the variables in percentage changes, and isolating reserves as the dependent variable, we may write the reserve flow equation as follows:

1. $\partial R=\partial[L(Y, P, 1)]-\partial D \ldots \ldots \ldots$

Equation 9 is the fundamental monetary approach to balance of payments equation. It postulates that the balance of payments is the outcome of the divergence between the growth of the demand for money and the growth of domestic credit, with the monetary consequences of the balance of payments bringing the money market into equilibrium. An increase in domestic credit brings about an opposite and equivalent change in international reserves, given a stable demand function for money. The coefficient of $\partial D$ is thus known as an offset coefficient. It shows the extent to which changes in domestic credit are offset by changes in international reserves. The monetary approach predicts a value of minus unity for this coefficient in the reserve flow equation. Most of the empirical studies on the monetary approach confirm this result. (See for instance, Kannan, 1989; Dhliwayo and Moyo, 1990; and Sohrab, 1985).

\section{Model Specification}

This research investigates the role of monetary channel on the balance of payment adjustment mechanism in Nigeria from (1970 - 2010). In Nigeria, many known researchers have identified the contemporary relationship between balance of payment and other macro-economics monetary variables, however this study will also want to establish if such relationship still exist and it direction. This study adopts the general framework of balance of payment (BOP) as described by Kallon (1994), and the money supply equation by Johnson (1976).

The simple open-economy LM model is employed to derive the long-run (BOP) balance of payment equation. The equation is of the form: 
1. $M_{t}=b_{1} Y_{t}+b_{2} R_{t}+b_{3} O P_{t} \quad\left(b_{1}>0, b_{2}, b_{3}<0\right)$

The above model is money market equilibrium, is assumed to depend on real income (Y), domestic interest rate $(R)$ and domestic inflation rate $(P)$. For the model below, balance of payment (BOP) stability is assumed to be the dependent variable while real income $(Y)$, relative price of imported goods $\left(\mathrm{P}_{\mathrm{f}}\right)$ and exchange rate $\left(\mathrm{R}^{\prime \prime}\right)$. Hence, the balance of payment (BOP) equilibrium equation is of the form:

$B O P_{t}=Q_{1} Y_{t}+Q_{2} P_{F t}+Q_{3} R_{t}^{\prime \prime} \quad\left(Q_{1}<0, Q_{2}, Q_{3}>0\right)$

Where: $\mathrm{R}^{\prime \prime}=$ Foreign interest rate, exchange rate, domestic interest rate.

The money supply equation is of the form:

1. $M^{s}=(R+D)$

$\mathrm{M}^{\mathrm{s}}=\mathrm{R}$ or

$M^{s}=D$

Where: Ms = Money supply, $\mathrm{R}=$ foreign reserves, $\mathrm{D}=$ Domestic credit

However, to achieve the objectives of this study, the above models are refined to a simple linear regression model and presented as below; which shows functional relationship that exist between the dependent variable and it respective independent variables.

Assumptions:

$\mathrm{Mt}_{\mathrm{t}}=\mathrm{b}_{1} \mathrm{Y}_{\mathrm{t}}+\mathrm{b}_{2} \mathrm{R}_{\mathrm{t}}+\mathrm{b}_{3} \mathrm{OP}$

$\triangle \mathrm{BOP}=\Delta \mathrm{Mtand} \Delta \mathrm{Mt}=\Delta \mathrm{Ms}$

$\Delta \mathrm{Ms}=\Delta \mathrm{Y}, \Delta \mathrm{Ms}=\Delta \mathrm{P}, \Delta \mathrm{Ms}=\Delta \mathrm{D}+\Delta \mathrm{R}, \Delta \mathrm{Ms}=\Delta \mathrm{R}$

Simplified Model:

1. $B O P_{t}=\&_{0}+\& E_{1} E_{R_{t}}+\&_{2} I N F_{t}+\&_{3} B O T_{t}+\&{ }_{4} D C_{t}+\&{ }_{5} N G D P_{t}+U_{t} \ldots \ldots$.

$\partial \mathrm{BOP} / \partial \mathrm{EXR}=\&_{0}+\&_{1} \mathrm{EXR}_{\mathrm{t}}+\&_{2} I N F_{\mathrm{t}}+\&_{3} \mathrm{BO} \mathrm{T}_{\mathrm{t}}+\&_{4} \mathrm{DC} \mathrm{C}_{\mathrm{t}}+\&_{5} \mathrm{NGDP}_{\mathrm{t}}+\mathrm{U}_{\mathrm{t}} \partial \mathrm{BOP} / \partial \mathrm{DC}=\&_{0}+\&_{1} \mathrm{EXR}_{\mathrm{t}}+\&_{2} I N \mathrm{FF}_{\mathrm{t}}+$

$\&_{3} \mathrm{BOT}_{\mathrm{t}}+\&_{4} \mathrm{DC} \mathrm{C}_{\mathrm{t}}+\&_{5} \mathrm{NGDP}_{\mathrm{t}}+\mathrm{U}_{\mathrm{t}}$

$\partial \mathrm{BOP} / \partial \mathrm{GDP}=\&_{0}+\&_{1} E X R_{\mathrm{t}}+\&_{2} I N F_{t}+\&_{3} \mathrm{BOT}_{\mathrm{t}}+\&_{4} \mathrm{DC} \mathrm{C}_{\mathrm{t}}+\&_{5} \mathrm{NGDP}_{\mathrm{t}}+\mathrm{U}_{\mathrm{t}}$

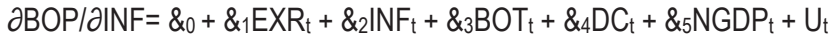

$\partial \mathrm{BOP} / \partial \mathrm{BOT}=\&_{0}+\& \mathrm{EXR}_{\mathrm{t}}+\&_{2} \mathrm{NNF}_{\mathrm{t}}+\&_{3} \mathrm{BOT}_{\mathrm{t}}+\& \mathrm{~B}_{4} \mathrm{DC}+\mathrm{C}_{\mathrm{t}}+{ }_{5} \mathrm{NGDP}_{\mathrm{t}}+\mathrm{U}_{\mathrm{t}}$

Where:

$\mathrm{BOP}=$ Balance of payments

$\mathrm{EXR}=$ Exchange rate $(\# / \$)$

INF = Inflation rate

$\mathrm{BOT}=$ Balance of trade $(\mathrm{X}-\mathrm{M})$

$\mathrm{DC}=$ Domestic Credit

GDP $=$ Nominal bill rate

$U=$ Error term

\subsection{Apriori Expectations}

Theoretically, it is expected that, low exchange rate will encourage importation in an import dependent economy like Nigeria. Hence the balance of payments will reduce causing disequilibrium in the BOP. In Nigeria, the relationship between balance of payment and exchange rate is negative i.e $\partial \mathrm{BOP} / \partial \mathrm{EXR}<0$.

It is also expected that Domestic credit would have a negative relationship with balance of payment. i.e $\partial \mathrm{BOP} / \partial \mathrm{DC}$ $<0$.

Generally, it's also expected that the growth of GDP will increase when export exceed import which invariably increase the balance of payment. i.e $2 \mathrm{BOP} / \mathrm{\partial GDP}>0$.

Moreover, when there's inflation in an economy people tends to rely on imported goods whose price dose not change, therefore it brings about unfavorably balance of payment. i.e $\partial \mathrm{BOP} / \partial \mathrm{INF}<0$.

Furthermore, when the balance of trade is favorable i.e when export is greater than import, then there's favorable balance of payment i.e $\partial \mathrm{BOP} / \partial \mathrm{BOT}>0$.

\subsection{Model Estimation Techniques}

In order to ascertain the relationship that exist between balance of payment and monetary variables as an adjustment mechanism, ordinary least square estimate (OLS) of linear regression is used to provide value for the coefficient of the models. To test the viability of the parameter estimate in this model, the coefficient of determination ( $R$ square) is 
employed to justify the explanatory power of the exogenous variable. Similarly, economics theory criteria are used to test the plausibility of the model while statistical criteria (t-test and f-test) are employed to evaluate the significance of the perimeter estimate and goodness of fit of the model. Econometric test is also adopted (standard error test).

\section{Data Analysis and Interpretation of Result}

This is designed to present and analyze the data collected in the course of the study and to make empirical analysis of the relationship between the dependent variable (Balance of Payments) and the explanatory variables (Exchange Rate, Inflation Rate, Balance of Trade, Domestic Credit, Gross Domestic Product).

It further obtains the parameter of the model specified earlier, evaluates the statistical significance of the value of the parameters obtained, interpret the results and compare with the "a priori" expectations.

\subsection{Analysis Of Result}

Dependent Variable: Real Gross Domestic Product

\begin{tabular}{|c|c|c|c|c|}
\hline Variable & Coefficient & Std. Error & t-Statistic & Prob. \\
\hline Exchange rate & 677.1542 & 384.163 & 0.176423 & 0.8611 \\
\hline Inflation rate & -3209.310 & 5224.385 & -0.614332 & 0.5431 \\
\hline Balance of trade & 0.291012 & 0.342221 & 0.851321 & 0.4010 \\
\hline Domestic Credit & 1.562411 & 0.806633 & 1.936442 & 0.0611 \\
\hline GDP & -0333642 & 0.141321 & -2.371321 & 0.0241 \\
\hline Constant & 12674.23 & 156120.8 & 0.081113 & 0.9360 \\
\hline
\end{tabular}

\section{Model Summary}

\begin{tabular}{l|l|l|l|l|}
\hline R-Squared & Adjustment R-Squared & F-Statistic & Durbin-Watson Statistic & Prob. F-Statistic \\
\hline 0.661211 & 0.611110 & 13.23001 & 1.303110 & 0.00000 \\
\hline BOP $=2674.23+677.15 \mathrm{EXCR}-3209310$ INFR + 0.291BOT + 1.562DC - 0.334GDP \\
S.E $=156120.83847 .1635224 .3850 .3420 .806$ & 0.141
\end{tabular}

\subsection{Interpretation Of Result}

The result of the model presented above shows that the explanatory variables (Exchange Rate, Inflation Rate, Balance of Trade, Domestic Credit, Gross Domestic Product) are determining factors of the Balance of Payment, with coefficient of multiple correlation been 0.980 or $98 \%$. The value of coefficient of multiple determination R-squared of 0.661 shows that $66.1 \%$ of the total variation in the dependent variable (Balance of Payments) is explained or brought about by the explanatory variables, while $33.9 \%$ variation is as a result of factors outside the model. The adjusted coefficient of determination R-squared of 0.611 indicates that provided the number of explanatory variables is expanded significantly, the coefficient of determination will only change slightly from 0.661 to $0.611(0.050 \%)$.

Generally, the analysis of the data used in the model reveal that one of the explanatory variables (INFR, BOT) has the expected signs. It is observed that Inflation Rate has a negative sign and Balance of Trade has a positive on Balance of Payments has expected, which is likewise theoretically plausible and found to be statistically significant.

Exchange Rate and Domestic Credit has a positive sign and Gross Domestic Product has a Negative sign, which is theoretically plausible but found to be statistically insignificant.

At the high degree of significance with the t-calculated value greater than the t-tabulated value of 2.02 at $5 \%$ level of significance. This is also supported by the fact that the standard error value of the coefficient is greater than half of the coefficient of the variable.

The null hypothesis $H_{0}$ is rejected while the alternate hypothesis $H_{1}$ is accepted and conclusion is made that monetary channel has significant role in Balance of Payment Adjustment Mechanism in Nigeria.

The F-statistic of $13.2309\left(F^{*}=2.85\right)$ shows that the model is statistically significant and that the independent variables are significant explanatory factors of the dependent variable. The above implies that the model has a goodness of fit and the Durbin Watson Statistic of 2.595 reveals that there is no serial correlation among the variables used in the model. 


\section{Conlusion and Recommendation}

Disequilibrium in balance of payment in any country is adjusted through various mechanisms which monetary measure is one of such adjustment mechanisms. The investigation into the monetary channel or approach of the Nigeria'sbalance of payment adjustment mechanism in indicated that balance of payment in actual fact, a monetary happenings and it's by and large true, that it is a basis of change in base money which could cause inconsistency in balance of payment this can subsequently correct the anomalies, if it application is done appropriately. It was revealed that monetary tools could effectively serve as adjustment mechanism to influence the balance of payment irregularities in Nigeria. Empirical proofs gathered in this work concluded that though not it entirety, balance of payments is palpably a monetary occurrence and any observed disequilibrium or instability in a country's balance of payment can be corrected via the adjustment of domestic credits demand and the quantity of balance of trade. So, the monetary authorities should adopt contractionary or restrictive monetary policy to reduce excessive growth of domestic credit, however exchange rate and balance of trade have strong influence on the direction of balance of payment. The government should also be cautious of budget deficit that are often time financed by internal borrowings.

In order to further entrench the Nigerian economy on the road map of sustainable economic growth and development as well as adjust the failed balance of payment policies and mechanisms in Nigeria which is terribly worsened by improper macro- economic policy mix (the application of monetary approach to the balance of payment, the strong role of devaluation under the conditions of imperfect and inflexible market structure). We recommend that the government must be cautious and foresighted in the adoption of any policy measures like monetary policies, economic policies and so on. Also, the government through the Central Bank of Nigeria should promote expenditure reducing policies by reducing money supply with a corresponding increase in interest rate and a fall in inflation rate to reduce demand for imported goods. Expenditure switching policies like direct control and devaluation of the currency to increase exportation of goods and local productions should also be encouraged, using direct control measures to manage importation of goods into the country.

Another recommendation is the need to manage domestic liquidity wisely in view of the tremendous pressure on the balance of payments of excess money. A determined effort to mobilize resources through private saving and the implementation of a prudent fiscal policy through efficient collection of tax revenues, rationalization of government expenditure towards growth enhancing and poverty reduction programmes will also enable the government to pursue its development programs without having to rely on the monetization of its budget deficit. Overall concentration on monetary tools solely should be reduced and employ other policy instruments to correct the balance of payment fluctuation. It is pertinent to know that no matter how effective monetary mechanism adjustment of balance of payment in any country, the government should always complement it with other effective policy measures to foster economic growth and development in the Nigerian economy.

\section{References}

Adamu P. A. and Itsede O. C. (2010) "Balance of Payments Adjustment: The West African Monetary Zone Experience". Journal of Monetary and Economic Integration Vol 10 No 2.

Adamu, P.A. (2003). "An Econometric Analysis of the Dynamics of Balance of Payments Adjustment in Ghana". Nigerian Economic and Financial Review, vol. 8, no. 2. December

Adamu, P.A. (2004). "The Dynamics of Balance of Payments Adjustment in Nigeria: An Error-Correction Approach". West African Financial and Economic Review, vol. 1, no. 2. African Econometrics, 3 (2), Pp. 199 - 230. December

Akpansung A. O. (1998), "Applicability of Monetary Approach to Nigeria's Balance of Payments,1960-1995".Unpublished M.Sc (Economics) Thesis, University of Calabar, Nigeria.

Akpansung A. O. (2013). "A Review of Empirical Literature on Balance of Payments as a Monetary Phenomenon". Journal of Emerging Trends in Economics and Management Sciences. Amsterdam: North Holland.

Alexander D. (2013) "Empirical Analysis of Balance of Payment in Ghana; Monetary Approach (1980-2010)". European Journal of Business and Management Vol 5, No 8.

Carbaugh R. J. (2004) "Balance of Payments Adjustments Under Fixed Exchange rate"; International Economics; 9th Edition, SouthWestern College Publishing. Chapter 14.

Central Bank of Nigeria (2006) Economic Report, Policy Measures

Dhliwayo R. (2004): "The Balance of Payment as a Monetary Phenomenon". Canadian Journal of Economics and Political Science, 29 (November),

Dhliwayo, R. (1996). "The Balance of Payments as a Monetary Phenomenon: An Econometric Study of Zimbabwe's Experience". African Economic Research Consortium (AERC), Research Paper 46. Nairobi.

Dhliwayo, R. and T. Moyo. (1990). "The Monetary Approach to Balance of Payments: A Case Study of Zimbabwe". Final Report, AERC, 
Nairobi.

Frenkel J and Mussa M (1976) "Asset Markets, Exchange Rates and the Balance of Payments". Journal of Economic Issues 26 (1) $262-$

270. Payments', in R Jones and P Kenen (eds) Handbook of International Economics, vol. 2,

Frenkel J. A and Johnson H. G. (1976), eds., "The Monetary Approach to the Balance of Payments" International Monetary Fund.

George Allen and Unwin, (1976), "The Monetary Approach to the Balance of Payments" International Monetary Fund,

Hume D (1752) 'Of the Balance of Trade' in R Cooper (ed) International Finance:

IMF (2006): Balance of Payment Manual (4th edition).

Imoisi A. I, Olatunji L. M. \&Ekpenyong B. I (2013). "Monetary Policy and Its Implications for Balance of Payments Stability in Nigeria: 1980-2010" International Journal of Economics and Finance; Vol. 5, No. 3

Imoisi, A. I. (2012) "Trends in Nigeria's Balance of Payments: an Empirical Analysis from 1970-2010"; European Journal of Business and Management. Vol 4, No.21,

Jhinga M. L. (2010) Macro Economy Theory, 12th Edition. Vrinda Publications Ltd.

Jimoh, A. (1990). "The Monetary Approach to Balance of Payments: Evidence from Nigeria". East African Economic Review, 6(1).

Jimoh, A. (2004), "The Monetary Approach to Exchange Rate Determination: Evidence from Nigeria". Journal of Economic Cooperation, 25(2):109- 130.

Johnson H (1977) "The Monetary Approach to the Balance of Payments: A Non-technical Guide", Journal of International Economics, 7 , 251-68.

Johnson, H. G. (1972), "The Monetary Theory of Balance of Payments Theory." Journal of Financial and Quantitative Analysis, March: $1555-1572$

Kennan, R. (1989). "Monetary Approach to Balance of Payments: A Case Study of India, 1968-1985". Economic and Political Weekly. 15(4): 627-636.

Kreinin, M.E. and L.H. Officer. (1978). "The Monetary Approach to Balance of Payments: A Survey". International Finance.No. 43. Princeton University, Princeton.

Mussa, M. (1976). "A Monetary Approach to Balance of Payments". Journal of Money, Credit and Banking. 6: 333-52.

Kallon, K. M. (1994), "An econometrics analysis of inflation in Sierra Leon", Journal of Economic Studies,

Mundel, R. A. (1971), "Monetary Theory", Pacific Palisades, California: Good Years.

Nwani V. M.(2003) Determinants of Balance of Payment Fluctuation In Nigeria(1981-2002)" Journal of Economic Studies.

Nyong, M. O. \&Obafemi, F. N. (1995) "Exchange Rate Policy and Macroeconomic Adjustment in Nigeria: A Theoretical and Empirical Analysis with Policy Implication" Journal of Economic Studies, 1(1), Department of Economics, University of Calabar.

Obioma, E. C. (1998). "Balance of Payments and Exchange Rate Management in Nigeria: Empirical Evidence from the Monetary Approach". NCEMA Policy Analysis Series.Vol. 4; No. 2.Technical Guide. Journal of International Economics. 7:251-68.

Polak J (1957) 'Monetary Analysis of Income Formation and Payments Problems', IMF Salin, P. Selected Readings, Harmonsworth: Penguin, 22-37.

Sohrab, H. (1985). "Monetary Approach to Balance of Payments: Evidence from Less Developed Countries" India Economic Journal.3: 92-104.116

Taylor, M. \& Spanos, A. (1984), "The Monetary Approach to the Balance of Payments: Staff Papers, 6, 1-50.

Table 1: Data on Balance of Payment, Exchange Rate, Balance of Trade, Domestic Credit Gross Domestic Product,

\begin{tabular}{|c|c|c|c|c|c|c|}
\hline Year & $\begin{array}{c}\text { Balance of } \\
\text { Payment (\#m) }\end{array}$ & $\begin{array}{c}\text { Exchange Rate } \\
(\# / \text { \$) } 1\end{array}$ & $\begin{array}{c}\text { Inflation Rate } \\
(\%)\end{array}$ & $\begin{array}{c}\text { Balance of Trade } \\
(\# \mathbf{m})\end{array}$ & $\begin{array}{c}\text { Domestic Credit } \\
(\# \mathbf{m})\end{array}$ & $\begin{array}{c}\text { Gross Domestic } \\
\text { Product (\#m) }\end{array}$ \\
\hline 1970 & 46.6 & 0.7145 & 1.8 & 129.2 & 1091.0 & 5281.1 \\
\hline 1971 & 117.4 & 0.6955 & 1.7 & 214.5 & 1227.0 & 6650.9 \\
\hline 1972 & 57.2 & 0.6579 & 9.4 & 444.1 & 987.3 & 7187.5 \\
\hline 1973 & 197.5 & 0.6579 & 4.6 & 1053.6 & 1057.2 & 8630.5 \\
\hline 1974 & 3102.2 & 0.6299 & 13.5 & 4057.5 & 1262.4 & 18823.1 \\
\hline 1975 & 157.5 & 0.6159 & 33.9 & 1204.0 & 1675.5 & 21475.2 \\
\hline 1976 & -339.0 & 0.6265 & 21.1 & 1602.6 & 2626.9 & 26655.8 \\
\hline 1977 & -527.2 & 0.6466 & 21.5 & 537.0 & 3406.7 & 31520.3 \\
\hline 1978 & 1293.6 & 0.6060 & 13.3 & -2147.3 & 4813.7 & 34540.1 \\
\hline 1979 & 1868.9 & 0.5957 & 11.7 & 3364.3 & 7214.0 & 41974.7 \\
\hline 1980 & 2402.2 & 0.5464 & 10.0 & 5091.1 & 8215.6 & 49632.3 \\
\hline 1981 & -3020.8 & 0.6100 & 21.4 & -1816.3 & 11192.6 & 47619.7 \\
\hline 1982 & -1398.3 & 0.6729 & 7.2 & -2564.1 & 15007.6 & 49069.3 \\
\hline 1983 & -301.3 & 0.7241 & 23.2 & -1401.2 & 22221.4 & 53107.4 \\
\hline 1984 & -354.9 & 0.7649 & 40.7 & 1909.7 & 25672.1 & 59622.5 \\
\hline 1985 & -349.1 & 0.8938 & 4.7 & 4658.2 & 27949.1 & 67908.6 \\
\hline 1986 & -4099.1 & 2.0206 & 5.4 & 2937.0 & 28438.7 & 69147.0 \\
\hline 1987 & -17964.8 & 4.0179 & 10.2 & 12498.9 & 36789.1 & 105222.8 \\
\hline
\end{tabular}




\begin{tabular}{|c|c|c|c|c|c|c|}
\hline 1988 & -20795.0 & 4.5367 & 56.0 & 9747.1 & 47029.6 & 139085.3 \\
\hline 1989 & 22993.5 & 7.3916 & 50.5 & 27111.0 & 47049.6 & 216797.5 \\
\hline 1990 & -5761.9 & 8.6378 & 7.5 & 64168.2 & 84093.1 & 267550.0 \\
\hline 1991 & -15796.6 & 9.9095 & 12.7 & 32047.2 & 116198.7 & 312139.7 \\
\hline 1992 & -101404.9 & 17.2984 & 44.8 & 62460.5 & 177961.7 & 532613.8 \\
\hline 1993 & -41736.8 & 22.0511 & 57.2 & 53140.7 & 273836.4 & 683869.8 \\
\hline 1994 & -42623.3 & 21.8861 & 57.0 & 43270.4 & 407582.7 & 899863.2 \\
\hline 1995 & -195316.3 & 21.8861 & 72.8 & 195533.7 & 477733.93 & 1933211.6 \\
\hline 1996 & -53152.0 & 21.8861 & 29.3 & 746916.8 & 419975.56 & 2702719.1 \\
\hline 1997 & 1076.3 & 21.8861 & 10.7 & 395946.1 & 501751.15 & 2801972.6 \\
\hline 1998 & -220675.1 & 21.8861 & 7.9 & -85562.0 & 560830.21 & 2708430.9 \\
\hline 1999 & -326634.3 & 92.6934 & 6.6 & 326454.1 & 794806.6 & 3194015.0 \\
\hline 2000 & 314139.2 & 102.1052 & 6.9 & 960700.9 & 898253.90 & 4582127.3 \\
\hline 2001 & 24738.7 & 111.9433 & 18.9 & 509773.5 & 1016974.00 & 4725086.0 \\
\hline 2002 & -565353.3 & 120.9702 & 12.9 & 231482.3 & 1166000.70 & 6912381.3 \\
\hline 2003 & -162839.7 & 129.3565 & 14.0 & 1007651.1 & 1257120.00 & 8487031.6 \\
\hline 2004 & 1124157.2 & 133.5004 & 15.0 & 2615736.3 & 1297765.20 & 11411066.9 \\
\hline 2005 & -2394864 & 132.1470 & 17.9 & 4445678.5 & 1275076.57 & 14572239.1 \\
\hline 2006 & -2206500.50 & 128.6516 & 8.2 & 4216161.3 & 2082007.3 & 18564594.7 \\
\hline 2007 & -2124143.63 & 125.8331 & 5.4 & 4397805.7 & 2941813.48 & 20657317.7 \\
\hline 2008 & -2335513.79 & 118.5669 & 11.6 & 4971687.5 & 2320310.00 & 24296329.3 \\
\hline 2009 & -3913279.36 & 148.9017 & 12.4 & 3253851.2 & 3228030.00 & 24794238.7 \\
\hline 2010 & -814177.45 & 150.2980 & 12.4 & 3030420.3 & 4551820.00 & 29205783.0 \\
\hline
\end{tabular}

Sources: National Bureau of Statistics Bulletin 2010, CBN Statistical Bulletin Volume20, CBN Annual Reports and Statement of Account. 